「繊維メーカーとバイオテクノロジー」特集

\title{
通産省のバイオインダストリー施策と 産業界の学界への期待
}

\section{1.はじめに}

昨年 6 月，当省は，事業者が組換え DNA 技術の成果 を鉱工業等の産業活動に利用する場合のうち, 工業プロ セスで利用する際の安全確保のための基本的要件を示し, 組換え DNA 技術の利用に係る安全確保に万全を期し, あってその技術の適切な利用を促進することを目的とし て，「組換えDNA 技術工業化指針」を策定・告示した。 同指針は，事業者は設備・装置等が指針に適合してい るととの確認を通商産業大臣に求めるととができるとと としており，今年 7 月までに，延べ 15 社 68 件の工業化 計画が指針に適合しているとの確認を受けるなど，わが 国むいよいよ組換えDNA 技術実用化の時代を迎えた。

\section{2. 研究開発動向}

わが国に抢けるバイオテクノロジーの研究開発動向を 総務庁統計局が毎年実施している「科学技術研究調査に 付帯するライフサイエンス研究調查報告」によりみてみ るとととする。

昭和 60 年度のライフサイエンス研究費総額は 8838 億円で，科学技術研究費総額の $9.9 \%$ を占めており，対 前年度増加率は, $12.7 \%$ 増之 59 年度の伸び ( $5.6 \%$ 增)を 上回った。

研究主体別にみると, 会社等が 4285 億円, 大学等が 3444 億円, 研究機関が 1110 億円となっており，59 年度 と比べると, 会社等は $15.5 \%$ 增之調查開始以降最大の伸 びを示し, 研究機関は $12.7 \%$ 増, 大学等は $9.4 \%$ 増とそ れぞれ増加になっている。

また，科学技術研究費総額に占めるライフサイェンス

\section{田 巻 光 芳}

研究費の割合を研究主体別にみると，大学等が $19.2 \%$ ， 研究機関が $9.6 \%$ ，会社等が $7.2 \%$ となっており，大学等 の割合が最も大きい。

ライフサイエンス研究費のうち，民間が 6054 億円， 国・地方公共団体が 2784 億円それぞれ支出しており， 両者の支出割合は，民間の $68.5 \%$ に対して，国・地方公 共団体は $31.5 \%$ となっている。

表 1 亿よると, 研究目的別にみ大場合, 保健・医療関 係が 6266 億円で，総額の $70.9 \%$ を占めている。以下， 生命現象・生物機能関係か 776 億円, 食糧資源の確保関 係が 576 億円，生物及びその機能の鉱工業利用関係，環 境保全関係，実験生物関係がそれぞれ 200 300 億円台 と続き, 生物のエネルギー開発への利用関係は 67 億円 と最も少なくなっている。

対前年度増加率化ついてると，環境保全関係が 21.1 \%增で高い伸びを示し，次いで，生命現象・生物機能関 係, 生物及びその機能の鉱工業利用関係, 保健・医療関 係，実験生物関係，食糧資源の確保関係がそれぞれ11〜 14\%台の伸びとなっている。てれに対し，生物のエネル ギー開発への利用関係は $4.5 \%$ 減之なっている。

昭和 61 年 4 月 1 日現在のライフサイエンス研究関係 従事者数は 11 万 5900 人で, 乙のうち研究本務者数は 7 万 6200 人となっており, 60 年に比べ研究関係従事者数 は 7100 人， $6.5 \%$ ，研究本務者数は 4300 人， $6.0 \%$ それ ぞれ増加している。

ライフサイエンス研究活動のうち，特揭して調查した 遺伝子組換え研究の昭和 60 年度の研究費総額は 362 億 円で，ライフサイエンス研究費に占める割合は $4.1 \%$ に すぎないが，対前年度增加率は $46.5 \%$ 增と 59 年度の伸

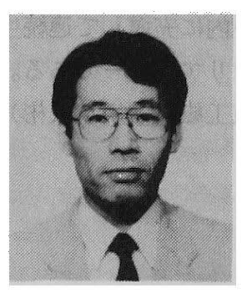

MITI's Policy and Expectation to Academic Circles

筆者紹介 MITSUYOSHI TAMAKI, Deputy Director, Bioindustry Office, Basic Industries Bureau, Ministry of International Trade and Industry, 通商産業省基碄産業局バイオインダストリー 室 室長補佐

筆者は東京工業大学化学工学科を昭和 54 年に卒業後直ちに通商産業省に入省され，生活産業局総務課， 絨維製品課, 産業構造課, 公害防止指導課に勤務ののち現職で活躍されておられる。趣味はスキー, 八イ キング, 絵画鑑賞。

本稿では，バイオインダストリーの将来見通しを踏まえて，行政サイドがどのように対応しているかを 明らかにされている。 
表 1 研究目的別研究費の推移

\begin{tabular}{|c|c|c|c|c|c|c|c|c|c|c|c|c|}
\hline \multirow[b]{2}{*}{ 区 } & \multirow[b]{2}{*}{ 分 } & \multicolumn{3}{|r|}{ 研 } & 究 & 目 & 勺 別 & 研 & \multicolumn{2}{|c|}{ 貫（億円） } & & \\
\hline & & 総 額 & $\begin{array}{l}\text { 生命現 } \\
\text { 象全般 } \\
\text { 及び生 } \\
\text { 物機能 } \\
\text { の解明 }\end{array}$ & $\begin{array}{l}\text { 実験生 } \\
\text { 物に関 } \\
\text { する咞 } \\
\text { 究開発 }\end{array}$ & 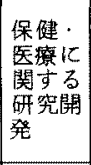 & $\begin{array}{l}\text { 環境保 } \\
\text { 全に関 } \\
\text { する研 } \\
\text { 究開発 }\end{array}$ & 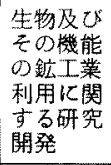 & 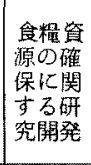 & $\begin{array}{l}\text { 生物のエ } \\
\text { 亦ルギー } \\
\text { 開発への } \\
\text { 利周に関 } \\
\text { する咞究 } \\
\text { 開登 }\end{array}$ & $\begin{array}{l}\text { その他 } \\
1 つ サ 1 \\
\text { エンスに } \\
\text { 閣する研 } \\
\text { 究 }\end{array}$ & $\begin{array}{l}\text { 自然科 } \\
\text { 学に螱 } \\
\text { する研 } \\
\text { 究 }\end{array}$ & $\begin{array}{l}\text { 人文. } \\
\text { 社会科 } \\
\text { 学犀 } \\
\text { 变る研 } \\
\text { 究 }\end{array}$ \\
\hline 螈 & $\begin{array}{l}56 \text { 年度 } \\
57 \\
58 \\
59 \\
60 \\
\quad \text { 会 社等 } \\
\text { 研究機関 } \\
\text { 大学 等 }\end{array}$ & $\begin{array}{l}5099 \\
6492 \\
7426 \\
7840 \\
8838 \\
4285 \\
1110 \\
3444\end{array}$ & $\begin{array}{r}471 \\
613 \\
729 \\
680 \\
776 \\
58 \\
68 \\
650\end{array}$ & $\begin{array}{r}168 \\
200 \\
208 \\
202 \\
226 \\
85 \\
27 \\
114\end{array}$ & \begin{tabular}{|r|}
3518 \\
4505 \\
5286 \\
5562 \\
6266 \\
3384 \\
473 \\
2409
\end{tabular} & $\begin{array}{r}206 \\
268 \\
272 \\
312 \\
378 \\
94 \\
187 \\
96 \\
\end{array}$ & $\begin{array}{r}190 \\
224 \\
256 \\
339 \\
386 \\
315 \\
44 \\
26\end{array}$ & $\begin{array}{r}341 \\
447 \\
458 \\
517 \\
576 \\
300 \\
225 \\
52\end{array}$ & $\begin{array}{l}93 \\
73 \\
63 \\
71 \\
67 \\
32 \\
25 \\
11\end{array}$ & $\begin{array}{r}112 \\
161 \\
155 \\
158 \\
163 \\
17 \\
59 \\
87\end{array}$ & $\begin{array}{r}103 \\
151 \\
143 \\
147 \\
149 \\
17 \\
55 \\
76 \\
\end{array}$ & $\begin{array}{r}9 \\
10 \\
12 \\
11 \\
14 \\
0 \\
4 \\
10\end{array}$ \\
\hline 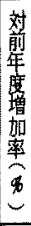 & $\begin{array}{l}57 \text { 年度 } \\
58 \\
59 \\
60 \\
\text { 会社 } \\
\text { 研学機関 } \\
\text { 大学等 }\end{array}$ & $\begin{array}{r}27.3 \\
14.4 \\
5.6 \\
12.7 \\
15.5 \\
12.7 \\
9.4 \\
\end{array}$ & $\begin{array}{l}30.3 \\
19.0 \\
-6.7 \\
14.1 \\
13.2 \\
28.5 \\
12.9 \\
\end{array}$ & $\begin{array}{r}19.0 \\
3.7 \\
-2.5 \\
11.8 \\
26.3 \\
9.4 \\
3.5\end{array}$ & \begin{tabular}{r|}
28.1 \\
17.3 \\
5.2 \\
12.7 \\
15.5 \\
13.3 \\
8.8
\end{tabular} & $\begin{array}{r}30.1 \\
1.4 \\
14.8 \\
21.1 \\
36.1 \\
18.8 \\
13.2\end{array}$ & \begin{tabular}{l|}
18.0 \\
14.3 \\
32.2 \\
13.8 \\
13.2 \\
14.7 \\
19.8
\end{tabular} & \begin{tabular}{r|}
31.1 \\
2.4 \\
12.8 \\
11.6 \\
19.1 \\
3.7 \\
7.8
\end{tabular} & $\begin{array}{r}-21.3 \\
-14.1 \\
12.4 \\
-4.5 \\
-0.8 \\
2.7 \\
-25.2\end{array}$ & $\begin{array}{r}44.2 \\
-3.6 \\
1.8 \\
3.2 \\
-40.0 \\
15.3 \\
10.8\end{array}$ & $\begin{array}{r}46.9 \\
-5.3 \\
2.5 \\
1.2 \\
-40.3 \\
13.6 \\
9.4\end{array}$ & $\begin{array}{c}11.7 \\
23.8 \\
-6.3 \\
29.2 \\
- \\
46.8 \\
22.6\end{array}$ \\
\hline 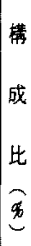 & $\begin{array}{l}56 \text { 年度 } \\
57 \\
58 \\
59 \\
50 \\
60 \\
\quad \text { 会 社 等 } \\
\text { 研究㙨関 } \\
\text { 大学 等 }\end{array}$ & $\begin{array}{l}100.0 \\
100.0 \\
100.0 \\
100.0 \\
100.0 \\
100.0 \\
100.0 \\
100.0\end{array}$ & $\begin{array}{r}9.2 \\
9.4 \\
9.8 \\
8.7 \\
8.8 \\
1.4 \\
6.2 \\
18.9\end{array}$ & $\begin{array}{l}3.3 \\
3.1 \\
2.8 \\
2.6 \\
2.6 \\
2.0 \\
2.5 \\
3.3\end{array}$ & $\begin{array}{l}69.0 \\
69.4 \\
71.2 \\
70.9 \\
70.9 \\
79.0 \\
42.6 \\
69.9\end{array}$ & $\begin{array}{r}4.0 \\
4.1 \\
3.7 \\
4.0 \\
4.3 \\
2.2 \\
16.9 \\
2.8\end{array}$ & $\begin{array}{l}3.7 \\
3.5 \\
3.5 \\
4.3 \\
4.4 \\
7.3 \\
4.0 \\
0.8\end{array}$ & $\begin{array}{r}6.7 \\
6.9 \\
6.2 \\
6.6 \\
6.5 \\
7.0 \\
20.3 \\
1.5\end{array}$ & $\begin{array}{l}1.8 \\
1.1 \\
0.8 \\
0.9 \\
0.8 \\
0.7 \\
2.3 \\
0.3\end{array}$ & $\begin{array}{l}2.2 \\
2.5 \\
2.1 \\
2.0 \\
1.8 \\
0.4 \\
5.3 \\
2.5\end{array}$ & $\begin{array}{l}2.0 \\
2.3 \\
1.9 \\
1.9 \\
1.7 \\
0.4 \\
5.0 \\
2.2\end{array}$ & $\begin{array}{l}0.2 \\
0.1 \\
0.2 \\
0.1 \\
0.2 \\
0.0 \\
0.4 \\
0.3\end{array}$ \\
\hline
\end{tabular}

注）総務打統㖕局「ライフサイエンス研究調査報告」上り

び24.3\%增を上回っており，顕著な伸びとなっている。 研究主体別にみると，会社等が 193 億内，研究機関か 88 億円，大学等が 81 億円で，会社等が総額の $53.2 \%$ を 占めている。

昭和 61 年 4 月 1 日現在の遗伝子組換え研究関係従事 者数は 4220 人で，うち研究本務者数は 2280 人之なって おり，60年に比へてそれぞれ $27.7 \%$ 增，22.2\%増上大幅 に增加している。

とのように産学官あげて精力的に研究が行われた結果， その成果である特許の出願件数も毎年急增している。表 2 亿よると，昭和 61 年に出願公開された特許の件数は，
組換えDNA 技術，細胞融合技術合計で前年比 $41 \%$ 增の 832 件に達している。うち外国からの出願は 384 件で全 体の $46 \%$ を占める。

出願件数の伸び率はわずかずつではあるが減少傾向に あるものの，毎年約 5 割の伸び率で增加しているという ことは，乙の分野の技術開発がすさまじい勢いで進めら れているととを雄弁に物語っていると言える。また，外 国加らの出願件数の全出願件数䎲占める割合は年々減少 傾向にあり，58 年以降は内国出願が過半を占めるなど， わが国のバイ才研究も本格化していることがうかがえる。 ちなみに，海外加らの遺伝子工学関係の国別特許公開件

表 2 遺伝子工学分野の特許公開件数

\begin{tabular}{|c|c|c|c|c|c|c|c|c|c|c|}
\hline 公開年 & $\begin{array}{l}52 \text { 年 } \\
\text { 以前 }\end{array}$ & 53 年 & 54 年 & 55 年 & 56 年 & 57 年 & 58 年 & 59 年 & 60 年 & 61 年 \\
\hline 組換えDNA技原 & 3 & 4 & 11 & 28 & 53 & 91 & 163 & 256 & 421 & 630 \\
\hline (j5外国出願) & (2) & (2) & $(8)$ & (22) & $(36)$ & (54) & $(78)$ & (129) & (221) & (313) \\
\hline 細胞融合技術 & 1 & 1 & 7 & 5 & 13 & 32 & 55 & 89 & 171 & 202 \\
\hline (う5外国出願) & (1) & $(0)$ & (5) & (4) & $(10)$ & (17) & (19) & (39) & $(69)$ & $(71)$ \\
\hline 計 & 4 & 5 & 18 & 33 & 66 & 123 & 218 & 345 & 592 & 832 \\
\hline (うち外国出頋) & (3) & (2) & (13) & (26) & (46) & (71) & $(97)$ & (168) & $(290)$ & $(384)$ \\
\hline
\end{tabular}


数をみると米国か断然トップで，以下英国，西独と続い ている。

\section{3. ハイイオテクノロジーの将来予測}

バイオテクノロジーの産業への応用は, 農林水産業, 食品工業，化学工業，資源エネルギー産業，電気・電子

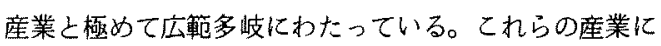
バイオテク/ロジーが応用さ机るととにより、はたして どのような経済的効果があるのであるうか。

昭和 60 年に(財)バイオインダストリ一協会が発表し た将来予測によると(図 1)，西暦 2,000 年には，わが国 の総生産額は 1,028 兆円(1980 年洒格, 以下同じ), うち バイオ系産業は127.2兆円である。総生産額 127.2 兆円 のうち，䤁造産業等卜ラディッショナルバイオテクノロ ジーに上るものが112.2兆网，組換えDNA技術，細胞 融合技術等のニューバイオテクノロジーによるものが 15.0 兆円である(図2)。なお，二ューバイオテクノロジ ーによるものは、トラディッショナルバイオテクノロジ
ーによるものに比べて付加価值率が高いととが特徽であ る。ちなみに, トラディッショナルバイオテクノジー の付加価值率は $35.6 \%$ なの対し、ーューバイオテク， ロジーのそれは $42.0 \%$ \% 6.4 ポイントも上回っている。 個別部門別の二ューバイオテクノロジーによるインパ クトをとりまとめたものが表 3 である。同表によると, ニューバイオテクノロジーの導入されるバイオ系部門は, 大別すると，(1)農林水産業，(2)食品工業，(3)紙・バルプ， (4)化学工業，(5医薬・農薬，6資源・エネルギー・ュー ティリティ，(7)電子・電機産業の7部門にわたると考元 られている。また，乙の他分析機器，試菂等の研究支援 産業が 3000 6000 億円の市場規模を有する産業仿つ あのと考えられている。

ての 15 兆円という数字は、ニューバイオテクノロシ 一の応用分野を想定して，技術の達成度を勘案して推計 したあのであるが，将来のてとを $100 \%$ 正確伅予測する ことは極めて团難である。現実には15 兆月にはほど遠 く数兆円にとどまるか子しれないし，逆に大きな゙飛躍が

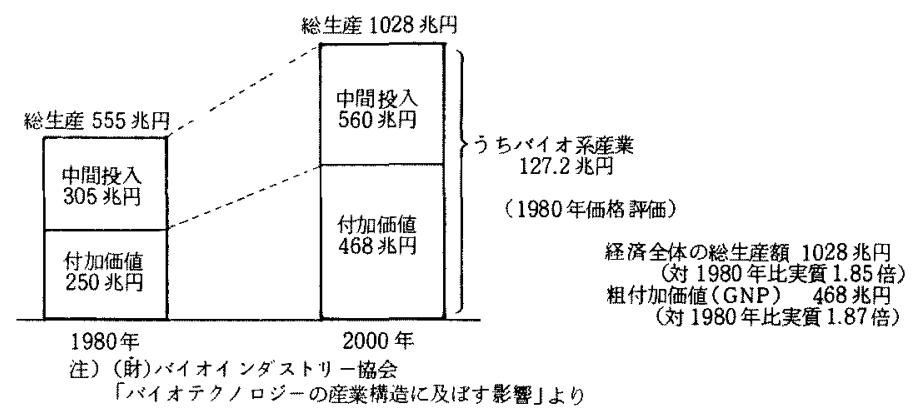

图12000年の経済規模

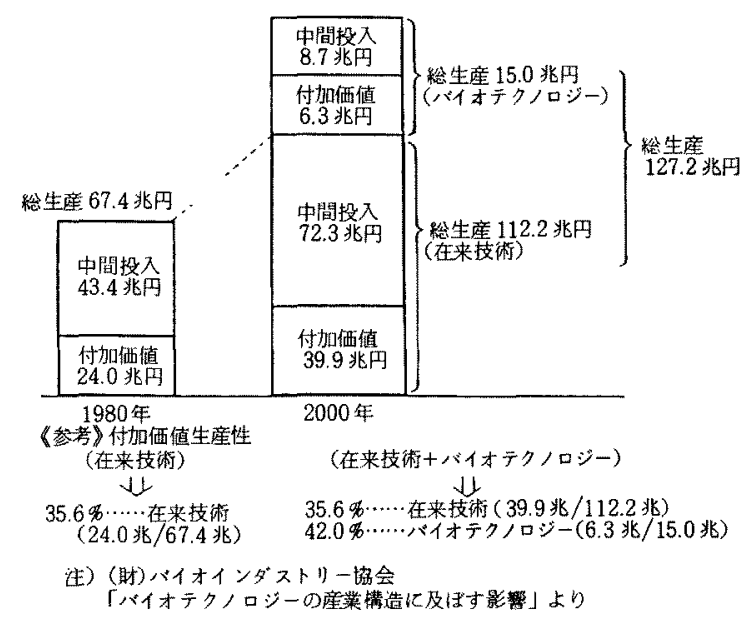

図 2 バイオテクノロジーによるバイオ系産業の規模 
表 32000 年に括けるバィオテクノロジ一の経済的インバクト

\begin{tabular}{|c|c|c|c|c|c|c|c|}
\hline ハイ才系部門名 & $\begin{array}{l}\text { パイオ } \\
\text { 技術 } \\
\text { 生産額 }\end{array}$ & 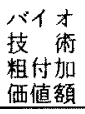 & $\begin{array}{c}\text { 産業技* } \\
\text { 術化摔 } \\
(\text { 另 })\end{array}$ & ハイオ才系部門名 & $\begin{array}{l}\text { バイオ } \\
\text { 挍赫 } \\
\text { 生原額 }\end{array}$ & $\begin{array}{l}\text { 公イ オ } \\
\text { 技術 } \\
\text { 粗扵加 } \\
\text { 洒值額 }\end{array}$ & $\begin{array}{l}\text { 産業技* } \\
\text { 体化摔 } \\
(\text { 呆 }\end{array}$ \\
\hline 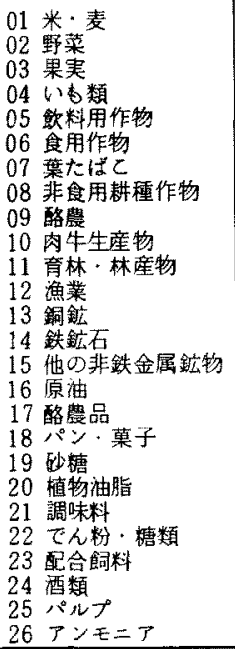 & $\begin{array}{r}519 \\
257 \\
13 \\
13 \\
2 \\
91 \\
12 \\
494 \\
327 \\
146 \\
9 \\
118 \\
17 \\
15 \\
2 \\
0 \\
590 \\
1,370 \\
108 \\
0 \\
251 \\
177 \\
637 \\
1,113 \\
90 \\
17 \\
\end{array}$ & $\begin{array}{r}381 \\
164 \\
9 \\
8 \\
1 \\
66 \\
9 \\
400 \\
111 \\
37 \\
7 \\
71 \\
13 \\
11 \\
1 \\
0 \\
150 \\
507 \\
13 \\
0 \\
73 \\
30 \\
58 \\
662 \\
17 \\
4\end{array}$ & $\begin{array}{r}9.51 \\
8.70 \\
1.20 \\
3.20 \\
0.80 \\
14.81 \\
4.10 \\
77.70 \\
25.00 \\
22.80 \\
0.66 \\
2.97 \\
20.00 \\
9.77 \\
2.00 \\
0 \\
26.70 \\
32.00 \\
10.00 \\
0 \\
15.00 \\
26.02 \\
30.00 \\
19.84 \\
5.00 \\
5.00 \\
\end{array}$ & 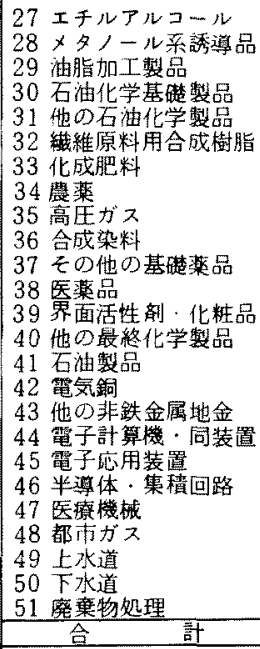 & $\begin{array}{r}164 \\
52 \\
75 \\
317 \\
753 \\
80 \\
0 \\
142 \\
64 \\
59 \\
73 \\
3,151 \\
466 \\
479 \\
463 \\
58 \\
242 \\
188 \\
287 \\
98 \\
31 \\
0 \\
479 \\
420 \\
471 \\
15,003 \\
\end{array}$ & $\begin{array}{r}49 \\
14 \\
19 \\
44 \\
116 \\
23 \\
0 \\
33 \\
28 \\
22 \\
34 \\
1.564 \\
155 \\
149 \\
79 \\
4 \\
46 \\
80 \\
103 \\
42 \\
15 \\
0 \\
303 \\
238 \\
349 \\
6,312 \\
\end{array}$ & $\begin{array}{r}80.00 \\
16.00 \\
32.00 \\
8.32 \\
14.50 \\
6.37 \\
0 \\
30.00 \\
11.00 \\
30.00 \\
41.00 \\
40.00 \\
20.00 \\
12.37 \\
1.65 \\
5.00 \\
6.24 \\
3.00 \\
5.00 \\
2.00 \\
3.00 \\
0 \\
24.00 \\
50.00 \\
15.63 \\
11.80 \\
\end{array}$ \\
\hline & & & & 研究支援産業 & & & \\
\hline
\end{tabular}

*代替率(バイオテクノロジ一が従来技術化代替する比率) ×寒現率

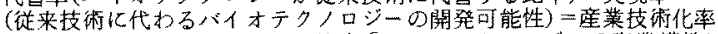

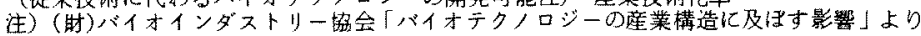

あって，15兆円を大きく上回るかもしれない。大切な てとは,一ューバイオテクノロジーが非常に大きな可能 生を持った技術であり，てれまでの物の作り方を革新す ることができるということである。そのポテンシャルに 期待し，よりスピーディに効率的にバイオテクノロジー の可能性を花開加せていくことが行政に携わる我々の責 務であると考え，現在，次汇紹介するような施策を講じ ている。

\section{4. 通産省のバイオインダストリー政策}

通産省のバイオインダストリー政策は 5 つの柱によ。 て構成されている(図3)。以下，その概要を紹介するこ ととする。

（1）政策全般の企画・檢討・ビジョンの作成

ハイオテクノロジーの技術開発動向の現状上見通しを 踏去えて産業の将来像を明らかにするとともに，その将 来像を実現するために解決すべき課題を検討している。

\section{（2）産業基般の整備}

産・学・官の連携の強化を図るため（財)バイオインダ ストリー協会(略称BIDEC; Bioindustry Development Center)の活動を積極的に支援している。なお，(財)バ イオインダストリ一協会は，本年 2 月，旧(財) 発酵工業
協会本部と同協会バイオインダストリ一振興事業部が統 合・改組のうえ発足した団体で，わが国唯一のバイオの 総合団体である。

また，バイオインダストリー関連産業である機器・試 薬産業の円滑な育成を図るため，標準化を推進している。 さらに，研究開発型企業の育成を図るため，基盤技術研 究促進センターの活動を支援している。てれまでに同せ ンターの出資を受けて設立されたバイ才系企業は $3 つ$ つ る。昭和 60 年度に設立されたのが，活性ぺプチドの遗 伝子操作及び化学合成法による製造法の確立と活性スク リーーング法の開発を目的とするエム・ディ・リサーチ (株)と, プロティン・エンジニアリングの研究開発を目 的亡する(株)蛋白工学研究所である。昭和 61 年度には， 植物細胞工学侄より有用物質を生産する技術の開発孝目 的とする(株)ピー・シー・シー・テクノロジー(Plant Cell Culture）が設立された。

\section{（3）技術開発の推進}

バイオテクノロジーは, 未だ研究開発が中心の段階で

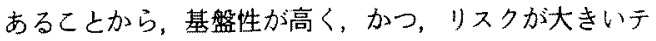
一マについては，国廭極的に支援して，技術開発を進 めるとともに，技術開発基盤の整備を図るため各種施策 を構じている。 
1. 振興策全般の企画・検討・ビションの作成………「バイオインダストリー振與委員会」，「バイオマス対策委員会」ての検討

2. 産業基盤の整借

業界の組織化, 㢈学官の連携強化

(財)バイオインダストリ一協会(BIDEC)の指導，'88 巢京国際バイオフ ×の開催

標準化の推進

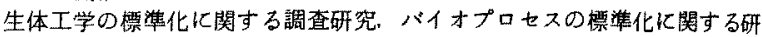
究, 工業標凖原案作成

咞究開発型企業の育成。 基盤技術研究促進センター，(肋)研究開発型企業育成センター（VEC)

3. 技術開発の推進

(1) 技術開発ブロジェクトの推進

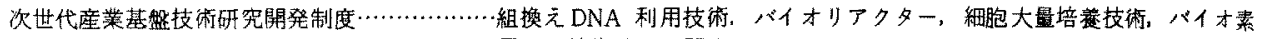
子の 4 技術分野の開発

座業活性化技街研究開発眷補助金制度

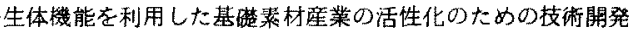

バイオマス関連技術開発 新燃料油開発技郝研究組合，燃料用了ルコール開発技術研究組合，パ才 マス委託調查

アルコール専売事業特別会䂥研咒開発調查……高生産性醉母による高勃率アルコール逨続発醉技術開発

轻質留分用途開発 歭質留分新用途開発技術研究組合

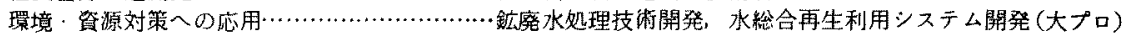

重要技術研究開発残補助金制度の活用

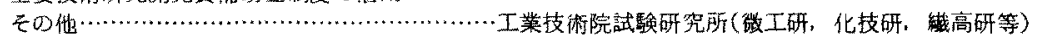

（2）技㫦開発基盤の整诵

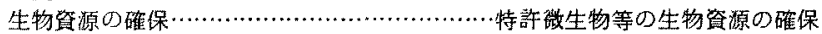

研究施設の整㳻……………………………日本開発銀行産業技術振與資金伜，基盤技術研究開発促進磁制の活用

4. 安全唯保対策

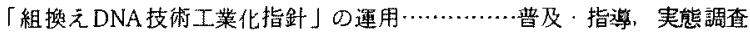

バイオインダストリー基盤強化調査

5. 国際協力の推進，地域活性化策の推進

地域におりる連携の強化………………………留談会の赛地(各地域)等

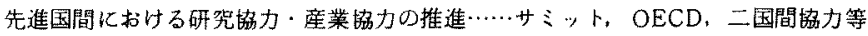

LDC への技術協力の推進……………………ビタミンンE(マレーシア)

ヒューマン・フロンティア・サイュンス プログラム

図3バイオインダストリ一政策体系

1）技術開発プロジェクトの推進

(1) 次世代産業基盤技術研究開発制度

バイオテクノロジーの基盤技術である組換えDNA

利用技術，ハハイオリアクター，細胞大量培養の 3 テ

ーマについて昭和 56 年度から産業界, 学界, 国の

協力のもとで研究開発を推進している。また，昭和 61 年度からバイ才素子の研究開発にも着手してい 万。

(2) 産業活性化技術研究開発費補助金制度 バイオテクノロジーを利用してファインケミカル

製品を製造する技術の開発を進めている。

(3) ハイオマス関連技術開発

セルロース資源，農林産廃棄物等のバイオマスか らバイオテクノロジーを利用して効率的に燃料用ア ルコールを生産する技術の開発を行っている。

(4) アルコール専䒿事業特別会計研究開発調查 高生産性醉母を用いて工業用アルコールを高効辩 で連続的に発醉させる技術の開発に昭和 62 年度か ら着手するとととしている。

(5) 大型工業技術研究開発制度（大プロ） 長期的な水需給逼迫化への対応，污濁物質の再資 源化を図るため，昭和60年度からバイオテクノロジ
一と膜分離技術を応用して，従来とは抜本的に異な る水総合再生利用システムの研究開発を行っている。 (6) その他

以上の国家プロジェクトの他，微生物工業技術研 究所をはじめとする工業技術院の各試験研究所にお いて国自ら様々な試験研究を行うとともに，重要技 術研究開発費補助金制度等を活用して民間企業の研 究開発を支援している。

2）技術開発基盤の整備

(1) 生物筫源の確保

バイオテクノロジーの研究開発を進めるに当たっ て必要不可欠な微生物や動植物細胞の収集・保存・ 分譲を行う体制を整備するため，微生物工業技術研 究所の特許微生物寄託センターを拡充するととあに, 動植物細胞実験棟の整備を行っている。

(2) 研究施設の整倩

バイオテクノロジー分野の研究開発に必要な機器

・装置類の取得を円滑に行いうるようにするため, 基盤技術研究開発促進税制及び固定資産税の課税標 準の特例を設け税制面から支援するとともに，日本 開発銀行に特別の融資枠を設け金融面からあ支援し ている。 
(3) データベースの整備

バイオテクノロジー関係のデータベースを整備す るため，昭和61年度，BIDECにおいてフィージビ リティスタディを行ったところであるが，昭和 62 年度は F/S の結果を踏まえて，プロトタイブのデ ー夕ベースの試作に着手している。

\section{（4）安全確保対策}

組換えDNA技術は既に述べたように化学工業をはじ めとする多くの産業分野において多大なインパクトを与 元る6のとして期待されている。一方，組換えDNA技 衡は当初想定されていたはど台険なものではないよが わかってきたものの，現在の知見のもとでは，特別の危 険を生じることがないとは必ずしも断言することはでき な。

このため組換えDNA技術の安全確保に万全を期しも ってその産業に枋ける適切な利用を促進するため，昨年 6月「組換えDNA技術工業化指針」を策定・公表した。 指斩の概要は图4に示すと和りである。こ机までに(昭和 62 年7月現在)同指針に基づいて延べ 15 社 68 件の工業 化計画か確認を受けているが，生産物は，アミ/酸・酵 素・武薬の3 種類である。
さらに，同指針は，アミ/酸の製造等工業プロセスで 組授え体を利用する場合の基本的要件を示したものであ るが，近年廃水処理等自然環境下で組換え体を利用する ととを領においた研究が活発化していることから，昭 和 61 年度加ら3ケ年計画で，自然噮境下で組換え体を 利用する際の安全確保策に関する基礎調查を実施してい 万。

\section{（5）地域活性化策之国際協力}

わか国は，古くから酒，みそ，しょう油等の釀造産業 が地域に密着した形で発展しており，地域における二ュ 一バイオテク/ロジーの潜在的ポテンシャルは高いもの がある。そこで，各地域においてバイオインダストリー に関する組織の設立が進められており，当省も各通産局 を通じてとれらの組織の活動を積極的に支援している。 また，各地のテクノポリスにおいてバイオテクノロジー を1つの柱としてとりあげていることから，ての面から も支援を行っている。

一方、バィオテクノロジーの研究開発は諸外国において も重要課題となっている。このため，サミット，OECD 等の場において多国間協力を推進するとと6に，各国之 の産業協力協議の場において二国間協力を進めている。

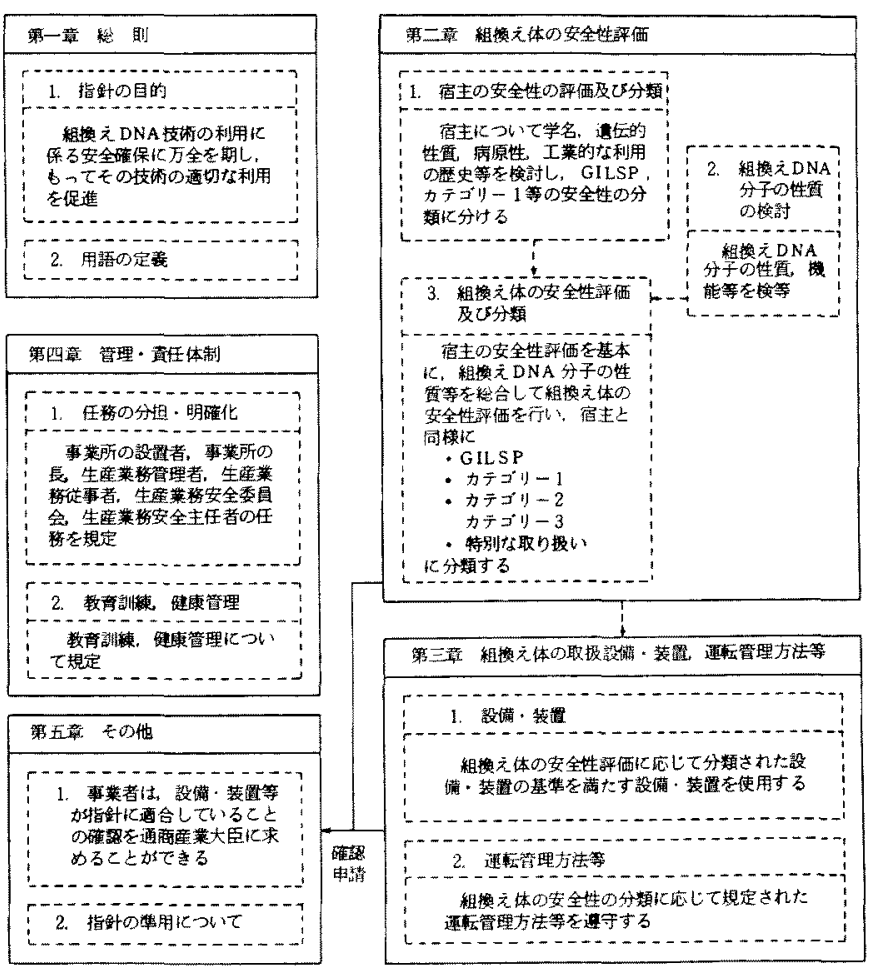

図 4 組換えDNA 技術工業化指針の概要 
また，生体の情報变換機能，エネルギー変換機能等各種 機能のメ力ニズムを国際的な協力体制のもと，解明する ため，ヒューマン・フロンティア・サイエンス・プログ ラムを提唱しており，本年 5 月に開催されたべネチアサ ミットに狲いてもそのフィージビりティスタディの推進 が宣言された。

一方，発展途上国汇対する技術協力几ついても，我が 国の国際的責務を果たすうえから積極的僬進すること としており，昭和 62 年度は, マレーシアに対してパー 么油の残渣加ら生理活性物質を抽出する技術に関して協 力を行っている。

\section{5. 学界への期待}

(財)バイオインダストリー協会(BIDEC) は，本年 3 月，企業に㧍㚈るバイオテク/ロジーの研究開発並びに 工業化の動向を把旺し，解決が望まれている技術上，制 度上等の問題点を把握することにより，今後のバイオテ クノロジーの研究開発並びに工業化の促進に資するとと を目的として，「バイオテクノロジー研究開発基盤に係 る調査報告書」をとりまとめた。当該報告書は，研究開 発の現状，工業化の現状上問題点，他機関之の業務提携， 共同研究等の現状等多岐にわたる項目について，民間企 業に詨するアンケート結果を分析し，とりまとめたあの である。

調查項目か極めて多㞳にわたっていることから，その 全容を紹介するてとは困難であるが，折角の機会なので， 調查結果のうち，学界に関係が深いと考えられる部分を 紹介することとする。

産業界の学界への期待というと, 誰もが先ず思い浮加 ベるのが人材育成である。をこでバイオ関係の人材を確 保するために，産業界か実施している方法を先ず紹介す ることとする。

図 5 亿よると，今回の調查でアンケートに回答を寄せ た126社のうち，大学(国内)への派遣之回答した企業が 98 社 $(78 \%)$ と最も多く，次いで，国立研究機関への派 遣が 79 社 (63\%)，外部専門家招へいが 44 社 (35\%) 之 続き，以下，バイオテク/ロジー尃攻の新規人材採用， 社内勉強会, サークルなどの順となっている。

次に，バイオテクノロジーの分野は基礎研究の成果が 直ちに実用化に反映される割合が他産業に比へて大きい と言われることから，その実態を紹介するとととする(図 6)。

图 6 亿よると大学之の業務提携・共同研究の内容亡し ては，共同研究開発が 44 社 (70\%) で最も多く，とのう 古人材交流老伴う共同研究が 24 社 (38\%)，人材交流を 伴わない共同研究が 20 社 (32\%) である。対他企業の場

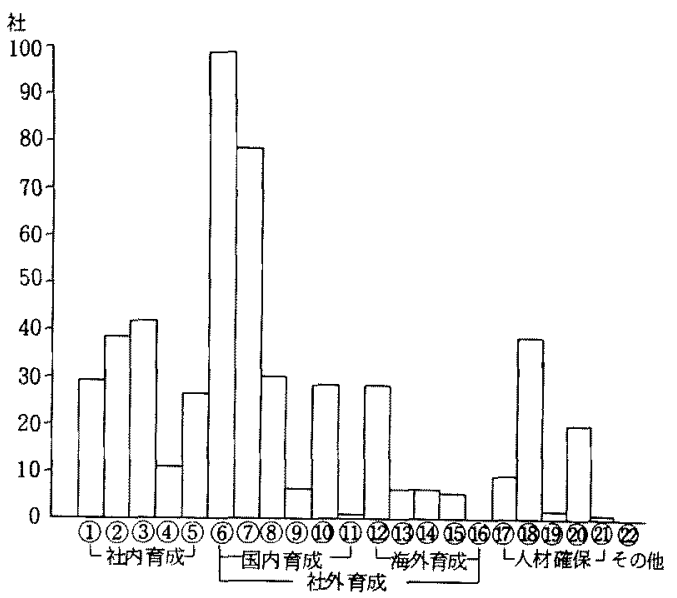

回答垻目

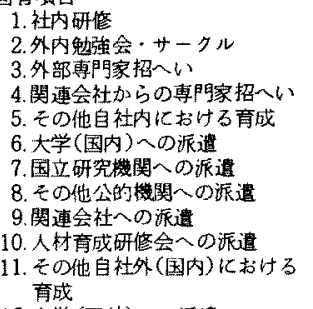

12.大学 (国外) への派逪

13. 公的機閏 (国外) 一の派遗

14.海外企栄心の派䢖

15.その儌外におりる育成

注）(財)ハイオインダトリー協会

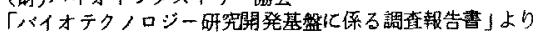

図 5 研究員の育成之確保の方法(回答 126 社)

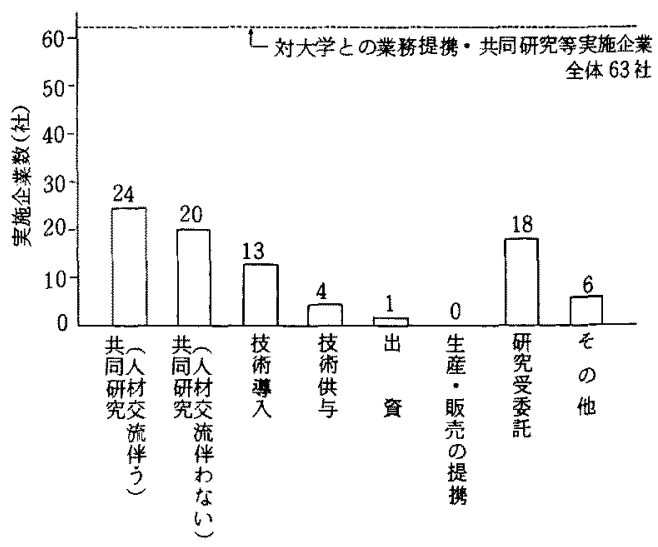

伡）(財)バイオインダストリー協会

「バイオテクノロジー研究開発基然に係召調不報告慧」より

図 6 対大学との業務提携・共同研究等の 形態，実施企業数

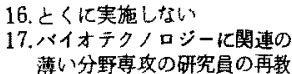

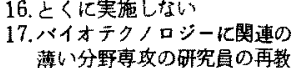
南

8.バイオテク/ロジー尃攻の啋 視人材探用(国内)

9.パイオテク/ロジ一曹政の新 視人材探用 (国外)

20.パイテクノロシー尃取の人 材を社の外部加らスカウト (国内)

21、ヘィオテクノロジー䙳攻す人 材童社の外部加らスカウト (国外) 2. 20 他

\section{.}


合と同槏共同研究が主流の形態である。次に研究受委託 が18社(29\%)で多い。研究内容 (テーマ、レベル等)か らみて自社で実施するより大学等へ委託する方が効率的 な場合研究委託がよく行われているととを示するのと考 えられる。た，技術導入 13 社 ( $21 \%)$ も比較的多く実 施されている(図6 参照)。

さらに，業務提擭・共同研究等について今後進めるて とを㛟討している相手方大学の系統は理学系 11 社 ( 52

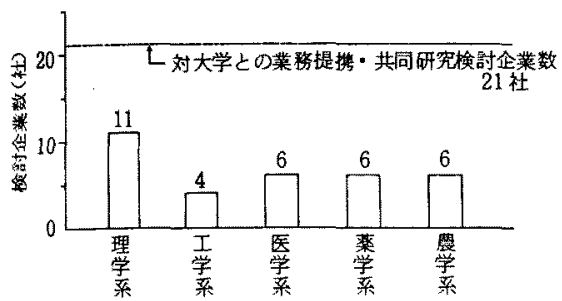

(住)（时）ハイオインダストリ一協会

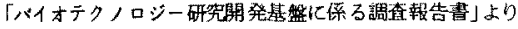

図7業務提携・共同研究等について今後進める てとを検討している相手方大学の系統・検 討企業数
\%) が最も多く，次汇医学系，薬学系，農学系が各々 6 社(29\%)となっており，バイオテク/ロジーの分野は基 喽研究のウエイトが高いことがうかがえる(図7参照)。

6.おわりに

わが国のバイオテクノロジーは，いよい上実用化の段 階に達したとてろであるが，新しい産業であるが故に統 計の整備等産業基盤の整備をはじめ多くの課題が存在し ている。バイオインダストリーは，既に拙文で述べたよ うに我汃国経済にとって極的て有益な産業分野を形成す るものと考えられていることから，現在抱えている課題 をいたずらにあせることなく克服していくことが我行 政に擭わる者の責務であると考えている。特に，バイオ テクノロジーは他の技術分野に比へ，基礎研究の成果が 直ちに実用化に反映されると言われている技術分野であ ることから，産学官の連携の強化が常に叫ばれている。 てのため，本誌のような学会誌を通じて我々の仕事を紹 介させて頂く機会を得たことは大变有益なととであり本 学会に深く感謝する次第である。

（昭和 62 年 7 月 20 日受理）

賛 助会 員入会 (3社3口)

三島製紙株式会社 安倍川製紙株式会社 荒川化学工業株式会社

正会員入会者 (32名)

上野中（本州製紙）

藤田 忠宏（旭化成）

大森 雅人（湊川女短）

大内 基弘（神崎製紙）

策田善彦 (岐阜大)

家室 宏邦 (日東紡)

辻本 直彦（王子製紙）

平嶋 英則 (片山化学工)

佐藤 友治（山陽国策パ）

正田 重 (徳山曹達)

硧口隆昌（京大）

真貝 哲夫（東京坛大）

古別府 聡（東大）

森田悌介（山形大）

長田英史（福井大）

井出 利彦（信州大）
佐々木坤彪（本州製紙）

稲葉 政満（東京芸大）

秋山 豉実（神崎製紙）

外林 仁志（十保製紙）

高福 正人（都立大）

大竹 利則 (王子製紙)

松尾 隆吉（王子製紙）

鍵野 豊和（山陽国策パ）

岩見旺 糺（山陽国策八゚）

冨崎 之夫 (伯東化学)

武田育子（文化女大）

学生会員入会者 (13名)

牧野重人（東大）

渡辺正介（東大）

羽田司(山形大)

清原真由美（信州大）
内藤 勉 (十條繁紙)

山㱦 明 (日本ケンブリッジセ)

上岡 帝司（神崎製紙）

松倉 紀男（十條製紙）

王野弘晃 (日東紡)

塚本 治夫（王子製紙）

野村 英作（和歌山県工試）

小林 晃夫（山陽国策八゚）

金子 英信 (大蔵省印刷局)

制根 秀雄 (ダイセル化学)

深川 伸隆（東大）

栗田茂央（山形大）

斉藤洋志美（山形大）

大島浩（信州大） 